\title{
SIGNIFICANCE OF ABERRANT CD 82 EXPRESSION IN PEDIATRIC ACUTE LYMPHOBLASTIC LEUKEMIA
}

\author{
Mohamed Tarek Aly***, T. A. Elkerdany**, Y.N.Elsakhawy** and \\ S. M. Mekkayah*
}

\begin{abstract}
**Clinical pathology department, $\& *$ Pediatric department, Faculty of Medicine, Ain shams University $* * *$ Misr University for science and technology Cairo, Egypt.

Corresponding author Mohamed Tarek Aly

Mobile: (+2) 01224215805

E.mail:

m.tarek.aly@gmail.com
\end{abstract}

Received: 21/6/2021

Accepted: 15/7/2021

\section{Online ISSN: 2735-3540}

\begin{abstract}
:
Background: Acute lymphoblastic leukemia (ALL) is the most common type of childhood malignancy. It is characterized by uncontrolled clonal proliferation of lymphoid blasts with reduced capacity to differentiate into mature cells. The CD82, an adhesion molecule, performs an important role in the interaction between Leukemic stem cells (LSCs) and their niche. It is aberrantly expressed in CD34+CD38- acute myelogenous leukemia cells. However, little is known regarding its expression and roles in pediatric ALL patients and its clinical characteristics.
\end{abstract}

Aim of the work: To assess CD82 expression in patients with pediatric acute lymphoblastic leukemia (ALL), and to evaluate the association with the clinical data.

Patients and Methods: This study included a total of 35 pediatric ALL patients and 35 age-matched normal children. Using flow cytometric assessment CD82 expression levels were measured in peripheral blood samples and bone marrow. Patients were recruited from Pediatric Oncology Unit, Ain-Shams University Hospitals, blood samples and bone marrow were collected from all patients. Diagnostic workup of ALL was done for all patients including: 1Complete blood picture 2-Leishamn stained peripheral blood and bone marrow smears 3-flowcytometric immunophenotyping.

Results: Flow cytometry expression showed a statistically significant difference between ALL patients and controls. The intensity of CD82 expression by flow cytometry in dim and bright expression showed a statistically significant difference between ALL patients and controls

Conclusion: A significantly higher expression of CD82 was detected in pediatric ALL patients compared to matching controls indicating that CD82 may play an important role in the diagnosis of pediatric $A L L$

Keywords: CD82, flow cytometry, ALL

\section{INTRODUCTION:}

Acute lymphoblastic leukemia (ALL) is the most common type of childhood malignancy and is characterized by uncontrolled clonal proliferation of lymphoid blasts with reduced capacity to differentiate into mature cells ${ }^{(\mathbf{1})}$. The therapeutic outcome for children with ALL has been markedly improved by risk-adapted treatments and supportive care over the past decades ${ }^{(2)}$. The cure rates have increased to $>80 \%$ in a lot of studies ${ }^{(3-6)}$. However, $15-20 \%$ of patients eventually relapse, which has become the main obstacle to further improve treatment ${ }^{(7)}$. 
The CD82 gene, also termed (KAI1), is a member of the tetraspanin superfamily (TM4SF) $)^{(\mathbf{8})}$. It is widely accepted that CD82 is associated with cell growth, differentiation and proliferation, T-cell activation, regulation activity, and adhesion of natural killer cells. In the context of cancer, CD82 is associated with integrins on the surfaces of various tumor cells ${ }^{(\mathbf{9})}$. Numerous clinical studies have demonstrated that CD82 is a valid metastasis suppressor gene. Loss of CD82 protein and mRNA was associated with a poor prognosis in some solid malignancies, including prostate, colon, lung, and breast cancer ${ }^{(10)}$. However, there are few studies on its expression level in malignant blood disease. Burchert et al. (11) reported that CD82 was overexpressed in peripheral blood isolated from patients with acute myeloid leukemia (AML), in leukemic cells from patients with chronic myeloid leukemia (CML) in the accelerated or blastic phase, and chronic lymphocytic leukemia (CLL).

It has been suggested that CD82 is abundantly expressed on primitive and hemopoietic progenitor cells ${ }^{(\mathbf{1 2})}$. It was identified that CD82 is aberrantly expressed in CD34+CD38- acute myelogenous leukemia cells ${ }^{(13)}$. Subsequently, the study demonstrated that CD82 regulates the adhesion and survival of LSCs. However, little is known regarding the expression and roles of CD82 in the bone marrow (BM) of pediatric patients with ALL, and the association between CD82 expression and its clinical characteristics. To date, to the best of our knowledge, no previous study has reported data about the association between CD82 expression in pediatric ALL and clinical significance.

In the present study, CD82 expression levels were measured in the peripheral blood and bone marrow of pediatric patients with ALL as well as the associations with clinical-pathological characteristics.

\section{AIM OF THE WORK:}

To assess CD82 expression in patients with pediatric Acute lymphoblastic leukemia (ALL), and to evaluate the association with the clinical data.

\section{PATIENTS AND METHODS:}

Patients and controls. A total of 35 pediatric patients with ALL (20 females and 15 males; age range, 1-18 years) were enrolled in the present study. All patients were diagnosed according to the World Health Organization classification (29). Blood samples and bone marrow were obtained from all patients. A total of 35 normal age-matched blood samples were obtained from healthy children. Patients were recruited from Pediatric Oncology Unit, Ain-Shams University Hospitals during the period from February 2019 to January 2020. Written informed consent was obtained from parents on behalf of the children enrolled. The present study was approved by Ain shams university ethical committee.

\section{Flow cytometry analysis of CD82- expressing cells:}

BM aspirate samples were processed on the same day of sample collection. They were isolated then they were centrifuged at $1,000 \mathrm{x} \mathrm{g}$ for $20 \mathrm{~min}$ at $20^{\circ} \mathrm{C}$ and analyzed using flow cytometric analysis. Bone marrow mononuclear cells (BMMCs) $(1 \mathrm{x}$ $10^{6}$ ) were incubated with $\mathrm{Fc}$ receptor saturation reagent (Beckman Coulter, Inc., Brea, CA, USA) for $20 \mathrm{~min}$ at $20^{\circ} \mathrm{C}$. Subsequently, BMMCs cells were stained with a fluorescein isothiocyanate-conjugated monoclonal antibody (mAb) anti-CD82 antibody (cat. no. 342108; BioLegend, Inc., San Diego, CA, USA), followed by incubation at room temperature in the dark for $20 \mathrm{~min}$. Immunoglobulin $\mathrm{G}$ ( $\mathrm{IgG}$ ) isotype staining was used as a negative control. 


\section{Statistical analysis:}

Data were analyzed using MedCalc $($ C version 18.2.1 (MedCalc $\subset$ Software bvba, Ostend, Belgium). Non-normally distributed numerical variables were presented as median and inetrquartile range and betweengroup differences were compared using the Mann-Whitney test. Categorical variables were presented as number and percentage and differences were compared using the Pearson chi-squared test or Fisher's exact test as appropriate.Correlations between continuous variables were tested using the Spearman correlation.

\section{RESULTS:}

Aberrant expression of CD82 in pediatric patients with ALL. Flow cytometry expression showed statistically significant difference between ALL patients and controls (table 1). CD 82 expression > 9.1\% sharply discriminates between cases of ALL and control without any overlap between both groups (sensitivity $100 \%$ and specificity 100\%) (Diagram 1,2).

The intensity of CD82 expression by flow cytometry in dim and bright expression showed statistically significant difference between all patients and controls (table 2) and (Diagram 3).

Table 1. CD82 expression in cases and controls

\begin{tabular}{|c|c|c|c|c|c|}
\hline \multirow{2}{*}{ Variable } & \multicolumn{2}{|c|}{ ALL $(\mathrm{n}=35)$} & \multicolumn{2}{c|}{ Controls $(\mathrm{n}=15)$} & P-value \\
\cline { 2 - 5 } & Median & $\begin{array}{c}\text { Interquartil } \\
\text { range }\end{array}$ & Median & $\begin{array}{c}\text { Interquartile } \\
\text { range }\end{array}$ & \\
\hline $\begin{array}{c}\text { CD82 expression } \\
(\%)\end{array}$ & 99.9 & $99.8-100.0$ & 4.2 & $2.7-6.8$ & $<0.001$ \\
\hline
\end{tabular}

Data are median and interquartile range.

$\dagger$. Mann-Whitney test.

Table 2. Proportion of patients with CD82 intensity of flourescence in cases and controls

\begin{tabular}{|c|c|c|c|c|c|}
\hline \multirow{2}{*}{ Variable } & \multicolumn{2}{|c|}{ ALL $(\mathrm{n}=35)$} & \multicolumn{2}{c|}{ Controls $(\mathrm{n}=15)$} & \multirow{2}{*}{ P-value } \\
\cline { 2 - 5 } & $\mathrm{N}$ & $\%$ & $\mathrm{~N}$ & $\%$ & $<0.001$ \\
\hline CD82 Dim & 8 & $22.9 \%$ & 14 & $93.3 \%$ & \\
\hline Bright & 27 & $77.1 \%$ & 1 & 6.7 & \\
\hline
\end{tabular}

Data are number (n) and percentage (\%). $\dagger$. Fisher's exact test.

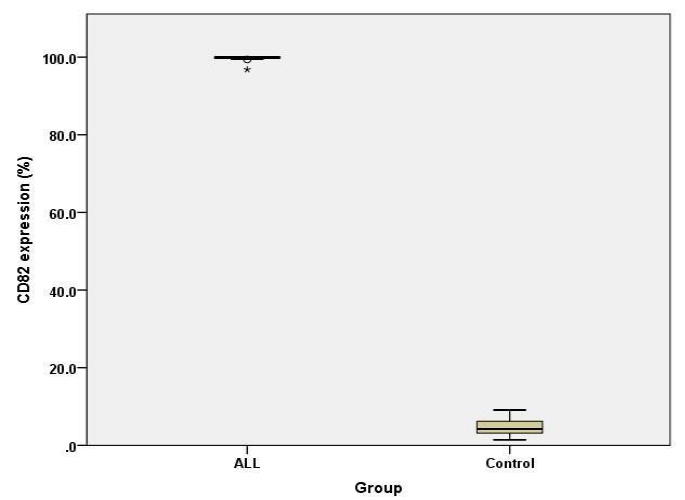

Diagram 1. Box plot illustrating CD82 expression in cases of ALL and controls. Markers represent individual observations. Box represents interquartile range. Horizontal line represents the median. Whiskers represent the minimum and maximum values excluding outliers (circles) and extreme values (asterisks). 
Mohamed Tarek Aly, et al.,

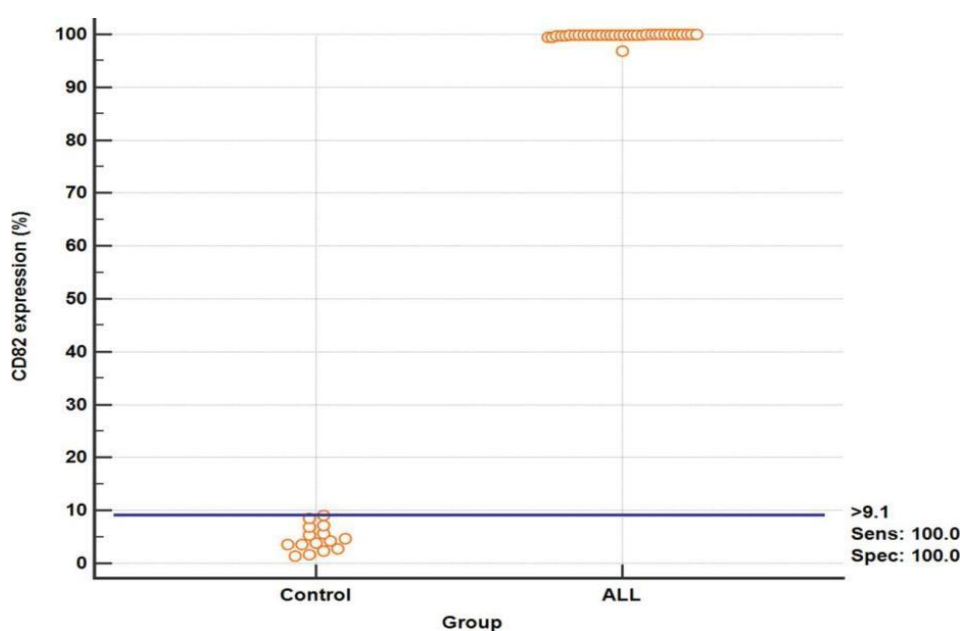

Diagram 2. Interactive dot diagram showing CD82 expression in cases of ALL and controls. CD 82 expression > 9.1\% sharply discriminates between cases of ALL and control without any overlap between both groups (sensitivity $100 \%$ and specificity $100 \%)$.

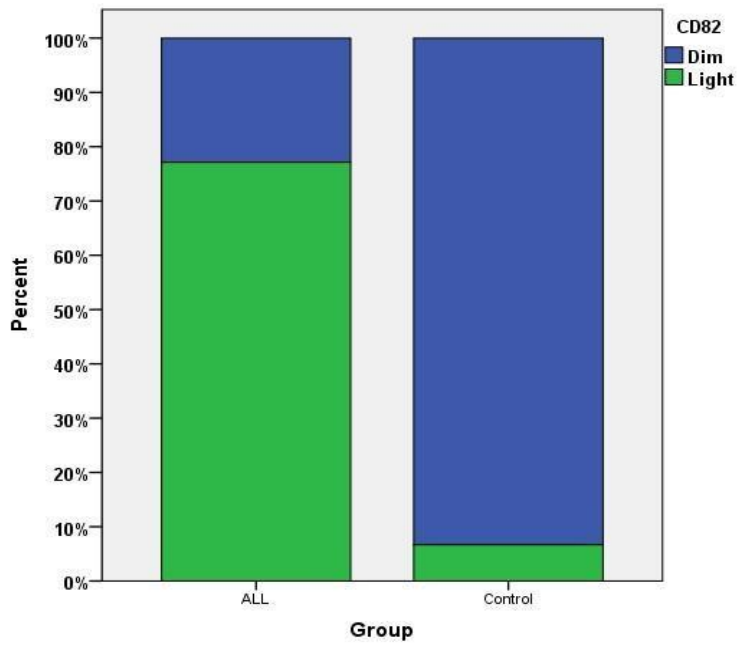

Diagram 3. Proportion of patients with bright or dim CD82 in cases and control.

There was a clinical and statistical significance between the cases with ALL and controls regarding the pattern of clinical presentations where some ALL cases showed lymphadenopathy, hepatomegaly and splenomegaly as shown in table (3).

Table 3. Pattern of clinical presentations in cases and controls

\begin{tabular}{|l|c|c|c|c|c|}
\hline & \multicolumn{2}{|c|}{ ALL (n=35) } & \multicolumn{2}{c|}{ Controls (n=115) } & \\
\hline Variable & $\mathrm{N}$ & $\%$ & $\mathrm{n}$ & $\%$ & $\mathrm{P}$-value $\dagger$ \\
\hline Clinical presentation & & & & & \\
\hline Lymphadenopathy & 19 & $54.3 \%$ & 0 & $0.0 \%$ & $<0.001$ \\
\hline Hepatomegaly & 23 & $65.7 \%$ & 0 & $0.0 \%$ & $<0.001$ \\
\hline Splenomegaly & 23 & $65.7 \%$ & 0 & $0.0 \%$ & $<0.001$ \\
\hline
\end{tabular}

Data are number (n) and percentage (\%). $\uparrow$. Fisher's exact test.

\section{DISCUSSION:}

CD82 gene is a member of the TM4SF that is located on human chromosome 11p11.2. It performs an important function in cell fusion, migration, adhesion, signaling, fertilization, differentiation and invasion. A previous study demonstrated 
that CD82 gene expression is underregulated in the majority of metastatic cancer types, which was in contrast to CD82 expression in malignant hematological disease. It had been revealed that CD82 was overexpressed in patients with CML in the accelerated or plastic phase, as well as in patients with AML detected aberrant expression of CD82 in CD34+CD38- AML cells. Importantly, it was revealed that down regulation of CD82 in CD34+CD38- AML cells could inhibit the adhesion and colony forming ability of these cells. In addition, in CD34+/CD38- AML cells, CD82 down regulation significantly impaired engraftment of the cells in severely immunocompromised patients. Taken together, the results suggested that aberrant CD82 expression may serve a role in the adhesion of LSCs to the BM microenvironment and in LSC survival ${ }^{(\mathbf{1 5})}$. Subsequently, (14) demonstrated that the CD82/signal transducer and activator of transcription 5/interleukin-10 signaling pathway is involved in the survival of CD34+/CD38- AML cells, while ${ }^{(\mathbf{1 6})}$ demonstrated the same for the p38-mitogenactivated protein kinase signaling pathway. Therefore, CD82 performs an important role in leukemogenesis. In the present study, the expression level of CD82 in the BM of pediatric ALL patients were evaluated. It was demonstrated that CD82 expression in the blood of all pediatric patients showed statistically significant difference between ALL patients and controls. In conclusion, the present study revealed that CD82 was aberrantly expressed in pediatric patients with ALL.

\section{Conclusion:}

There was a clinical and statistical significance between the cases with ALL and controls regarding the pattern of clinical presentations where some ALL cases showed lymphadenopathy, hepatomegaly and splenomegaly. Regarding the laboratory data patients with ALL showed increased CD82 expression, decreased WBCs, Hb levels and platelets count while controls showed decreased CD82 expression and normal WBCs, $\mathrm{Hb}$ levels and platelets count.

\section{REFERENCES:}

1. Pui CH, Robison LL and Look AT (2008): Acute lymphoblastic leukaemia. Lancet, 371: 1030-1043.

2. Pui $\mathrm{CH}$, Carroll WL, Meshinchi $\mathrm{S}$ and Arceci RJ (2011): Biology, risk stratification, and therapy of pediatric acute leukemias: An update. J Clin Oncol ,29: 551-565.

3. Möricke A, Zimmermann M, Reiter A, Henze G, Schrauder A, Gadner H, Ludwig WD, Ritter J, Harbott J, Mann G(2010): Long-term results of five consecutive trials in childhood acute lymphoblastic leukemia performed by the ALL-BFM study group from 1981 to 2000. Leukemia 24: 265-284.

4. Hunger SP, Lu X, Devidas M, Camitta BM, Gaynon PS, Winick NJ, Reaman GH and Carroll WL (2012): Improved survival for children and adolescents with acute lymphoblastic leukemia between 1990 and 2005: A report from the children's oncology group. J Clin Oncol 30: 1663-1669.

5. Conter V, Aricò M, Basso G, Biondi A, Barisone E, Messina C, Parasole R, De Rossi G, Locatelli F, Pession A(2010): Long-term results of the Italian Association of Pediatric Hematology and Oncology (AIEOP) Studies 82, 87, 88, 91 and 95 for childhood acute lymphoblastic leukemia. Leukemia 24: 255-264.

6. Pui CH, Campana D, Pei D, Bowman WP, Sandlund JT, Kaste SC, Ribeiro RC, Rubnitz JE, Raimondi SC, Onciu M(2013): Treating childhood acute lymphoblastic leukemia without cranial irradiation. N Engl J Med 360: 2730-2741, 2009.

7. Bhojwani D and Pui CH (2013): Relapsed childhood acute lymphoblastic leukaemia. Lancet Oncol 14: e205-e217.

8. Gil ML, Vita N, Lebel-Binay S, Miloux B, Chalon P, Kaghad M, Marchiol-Fournigault C, Conjeaud H, Caput D, Ferrara P (1992): A member of the tetra spans 
transmembrane protein superfamily is recognized by a monoclonal antibody raised against an HLA class I-deficient, lymphokine-activated killer-susceptible, B lymphocyte line. Cloning and preliminary functional studies. J Immunol 148: 28262833.

9. Miranti CK (2009): Controlling cell surface dynamics and signaling: How CD82/KAI1 suppresses metastasis. Cell Signal 21: 196211.

10. Mooez S, Malik FA, Kayani MA, Rashid R, Zahid A and Khan A. (2011) : Expressional alterations and transcript isoforms of metastasis suppressor genes (KAI1 and KiSS1) in breast cancer patients. Asian Pac J Cancer Prev 12: 27852791.

11. Burchert A, Notter M, Dietrich Menssen H, Schwartz S, Knauf W, Neubauer A and Thiel E. (1999): CD82 (KAI1), a member of the tetraspan family, is expressed on early haemopoietic progenitor cells and upregulated in distinct human leukaemias. $\mathrm{Br}$ J Haematol 107: 494-504.

12. Nishioka C, Ikezoe T, Furihata M, Yang J, Serada S, Naka T, Nobumoto A, Kataoka S, Tsuda M, Udaka K and Yokoyama A (2013): CD34 \pm CD38- acute myelogenous leukemia cells aberrantly express CD82 which regulates adhesion and survival of leukemia stem cells. Int J Cancer 132: 2006-2019.

13. Vardiman JW (2010): The World Health Organization (WHO) classification of tumors of the hematopoietic and lymphoid tissues: An overview with emphasis on the myeloid neoplasms. Chem Biol Interact 184: 16-20, 20.

14. Nishioka C, Ikezoe T, Yang J, Nobumoto A, Kataoka S, Tsuda M, Udaka K, Yokoyama A (2014): CD82 regulates STAT5/IL-10 and supports survival of acute myelogenous leukemia cells. Int $\mathbf{J}$ Cancer.; 134:55-64.

15. Nishioka C, Ikezoe T, Furihata M, Yang J, Serada S, Naka T, Nobumoto A, Kataoka S, Tsuda M, Udaka K, Yokoyama A(2013). $\mathrm{CD} 34 \pm \mathrm{CD}^{-}$acute myelogenous leukemia cells aberrantly express CD82 which regulates adhesion and survival of leukemia stem cells. Int $\mathbf{J}$ Cancer.; 132:2006- 2019.

16. Nishioka $\mathrm{C}$, Ikezoe $\mathrm{T}$, Yang J, Yokoyama A. (2015): Tetraspanin family member, $\mathrm{CD} 82$, regulates expression of EZH2 via inactivation of p38 MAPK signaling in leukemia cells. PLoS One.; 10:e0125017. 


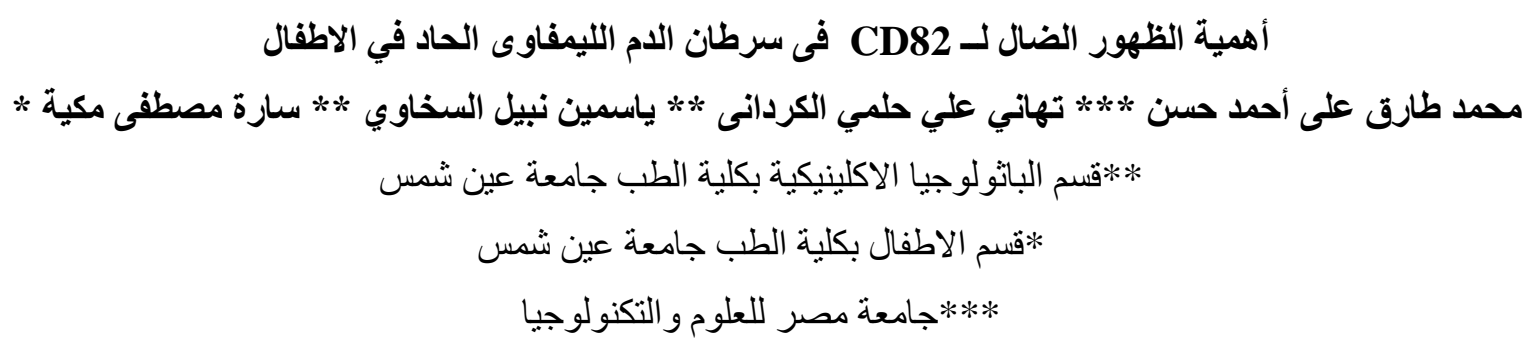

نبذة مختصرة

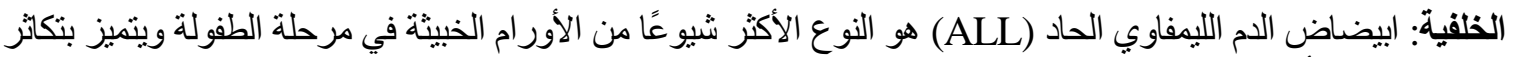

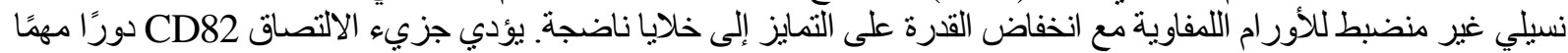

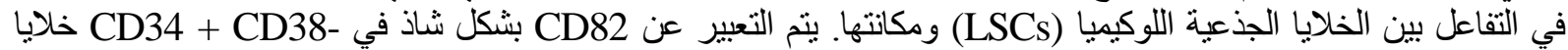

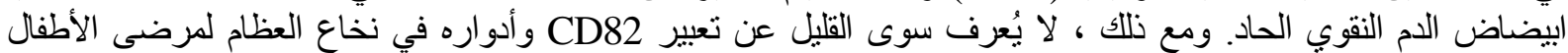

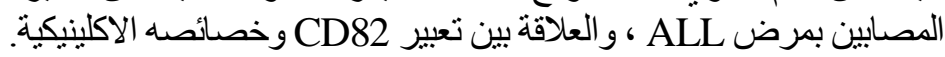

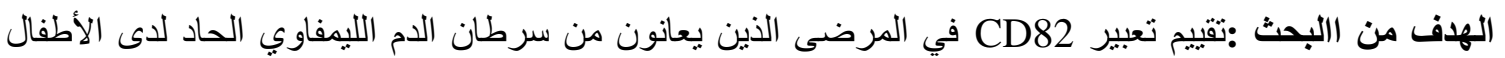
(ALL) ) وتقييم الارتباط بالبيانات الاكلينيكية.

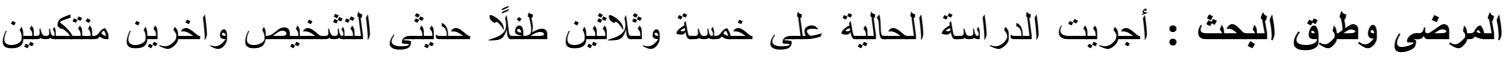

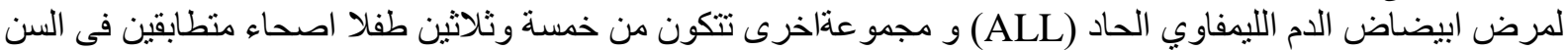
و الجنس كمجمو عة ضابطة خاليين من اى امر اض سرطانية لتقييم ظهور

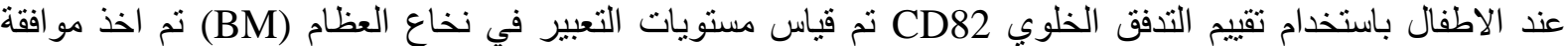

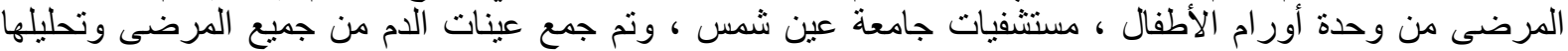

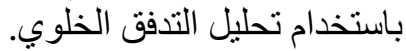

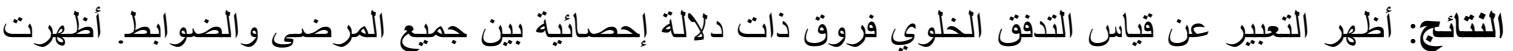

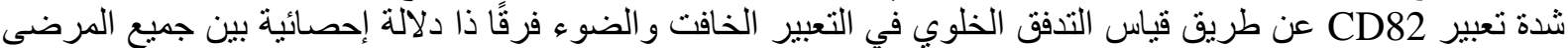
و الضو ابط

الخلاصة: قد يلعب CD82 دورًا مهمًا في تشخيص ALL عند الأطفال. لذلك ، يشير هذا العمل إلى تكامل CD82 كعلامة تشخيصية و إنذارية في ALL الكلمات الرئيسية: CD82 ، قياس التدفق الخلوي ، سرطان الدم الليمفاوى الحاد 